\title{
Statyba
}

\section{THE APPLICATION OF THE LINDO PROGRAM TO SOLVING LOCATION PROBLEMS FOR CONCRETE MIX PRODUCTION PLANTS}

\section{Celińska-Mysław \& O. Kapliński DSc, PhD, Eng.}

To cite this article: M. Celińska-Mysław \& O. Kapliński DSc, PhD, Eng. (1998) THE APPLICATION OF THE LINDO PROGRAM TO SOLVING LOCATION PROBLEMS FOR CONCRETE MIX PRODUCTION PLANTS, Statyba, 4:1, 56-63, DOI: 10.1080/13921525.1998.10531380

To link to this article: https://doi.org/10.1080/13921525.1998.10531380

Published online: 26 Jul 2012.

Submit your article to this journal $\llbracket$

Џll Article views: 147 


\title{
THE APPLICATION OF THE LINDO PROGRAM TO SOLVING LOCATION PROBLEMS FOR CONCRETE MIX PRODUCTION PLANTS
}

\author{
M. Celińnska-Mysław, O. Kapliński
}

\section{Introduction}

Problem of location belongs to the oldest optimization task in construction industry. It appears cyclically, according to the needs, new approaches, and new solution methods of this problem (cf Soderman [1], Skibicki [2], Daellenbach et al. [3], Harris \& McCaffer [4], Francis \& White [5], Kruse et al. [6]).

Therefore, there are many aspects of this problem. Let us mention the most characteristic ones and some examples:

- personnel management (personnel transfer problem) - cf Wright et al. [7],

- optimal placement of buildings, eg Baskaran \& Stathopoulos [8],

- arrangement of accommodations, eg Riopel \& Langevin [9],

- public investment and capital allocation, eg Georgi [10], Weingartner [11], Nemhauser \& Ullman [12],

- transport infrastructure location (in context: site planning), eg Olszewski [13], Prystupa [14],

- municipal management planning problems, such as:

- location of municipal objects, eg Huang et al. [15], Wijeratne \& Wirasinghe [16],

- environmental and regional planning - see: Meester [17], Suh et al. [18],

- location of prefabrication plants - see: Warszawski [19, 20, 21], Warszawski \& Ishai [22].

Separate aspects of this question are the location problems of the facilities on building site, eg Kamiński [23], Lennerts \& Knauer [24], Warszawski \& Peer [25].

Also, the planning of elements required for the management of a construction site for modernisation and investment purposes is a complicated process based on a proper understanding of contemporary trends. These problems require a unified technicaltechnological, organisational, utilitarian and economic approach. Under such conditions, methods utilising optimisation procedures are called for as these approaches should increase management effectiveness.

This paper presents a methodology for solving the location problems for a concrete mix plant based on prognoses of demand for concrete mix. It includes a method for calculating these quantities and deals with fundamental problems concerning the modelling of concrete mix plant location problems. Particular attention has been paid to the choice of a proper mathematical model and its solution. The paper is illustrated throughout with optimisation formulas for Poznań (Poland) and its environs - 700,000 inhabitants.

\section{Methodology for setting demand quantities of con- crete mix}

A question posing considerable difficulties is that of arriving at prospective demand quantities for concrete mix within a given region and in a defined time span.

Hitherto employed quantities considered in location problems have been obtained from the daily production records of individual concrete mix plants on an "ex post facto" basis. Accordingly, wrong decisions undertaken, additional costs accruing to investors etc could be determined. Due, however, to the unique nature of the construction industry, the dispersal and variety of investment projects and the variability of demand quantities for concrete mix, the quantities obtained by the above means needn't be appropriate in future situations.

Solution of location problems demands the ability to make accurate prognoses of future demand quantities. An attempt at making such prognoses is found in basing them on demand indices for concrete mix. Fig 1 illustrates the functioning algorithm. The basis for ascertaining the magnitude of the concrete mix demand indices was data obtained from technical documentation, technological and work organisation plans as well as cost estimates. 


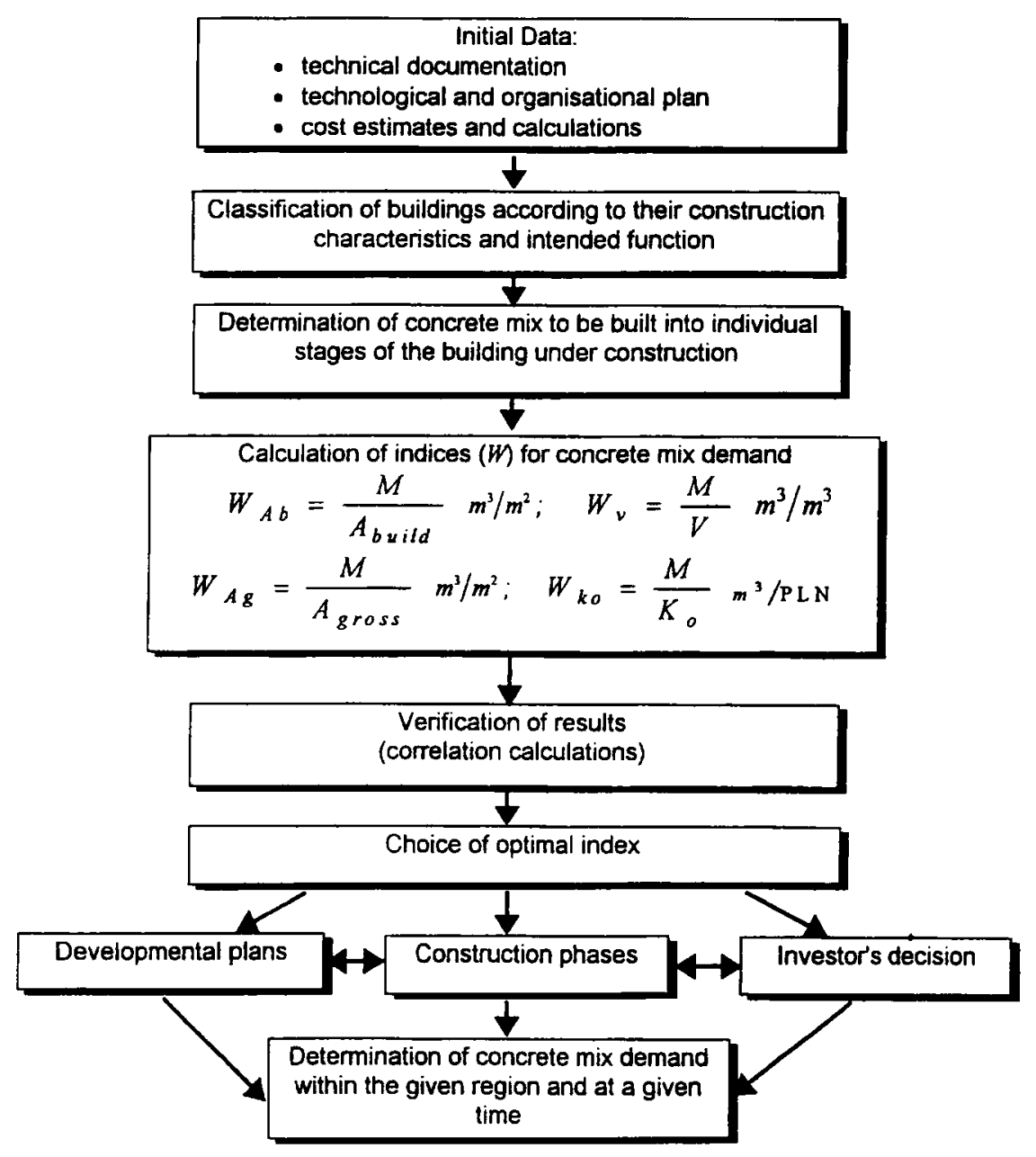

Fig 1. Algorithm for obtaining the given amount of concrete mix demanded: $M$ - amount of concrete mix $\left[\mathrm{m}^{3}\right]$; $A_{\text {build }}$ - area of building $\left[\mathrm{m}^{2}\right] ; A_{\text {gross }}$ - gross area $\left[\mathrm{m}^{2}\right] ; V$ - volume of building $\left[\mathrm{m}^{3}\right] ; K_{\mathrm{o}}$ - estimated value $[\mathrm{PLN}]$

It is on the basis of the above values, at each of the specific stages of the buildings' construction, that the amount of concrete mix built into the structure was determined. Demand indices determine the amount of concrete mix built into the individual stages of the buildings being constructed for each $1 \mathrm{~m}^{3}$ of the building volume per $1 \mathrm{~m}^{2}$ of the area under construction, each $1 \mathrm{~m}^{2}$ of the gross area and each 1-PLN of estimated value ( $₫ 1 \approx 5.0$ PLN). Separation into individual construction phases permits the demand for concrete mix to be determined within the time of the completed construction (cf Powell, [26]).

The determined value of the demand indices for concrete mix based on the building area and the gross area of buildings considered showed a significant dispersion of results. These must, consequently, be deemed as unreliable. Due to a sizeable rate of inflation (as exists in Poland), an attempt to determine the relationship between the amount of concrete mix built into individual buildings and its value in preliminary estimates was unsuccessful. It is, however, possible to determine future demand for concrete mix based on demand indices related to the volume of buildings. The statistical analysis conducted on individual buildings allowed for a determination of average values and standard deviation values. Values of concrete mix demand indices were determined on the basis of amounts obtained for 326 buildings.

The purpose of the buildings, the kind of construction they represented allowed the groups of buildings shown in Fig 2 to be analysed. Correlation showed linear dependencies between the amount of concrete mix built into the structure and the volume of the structure itself. Buildings having a larger overall volume showed smaller concrete mix demand indices. For those buildings where no functional dependence was found, average values ( - ), standard deviations $(S)$ and variation coefficients (v) were determined. Fig 3 presents values for certain groups of buildings. 


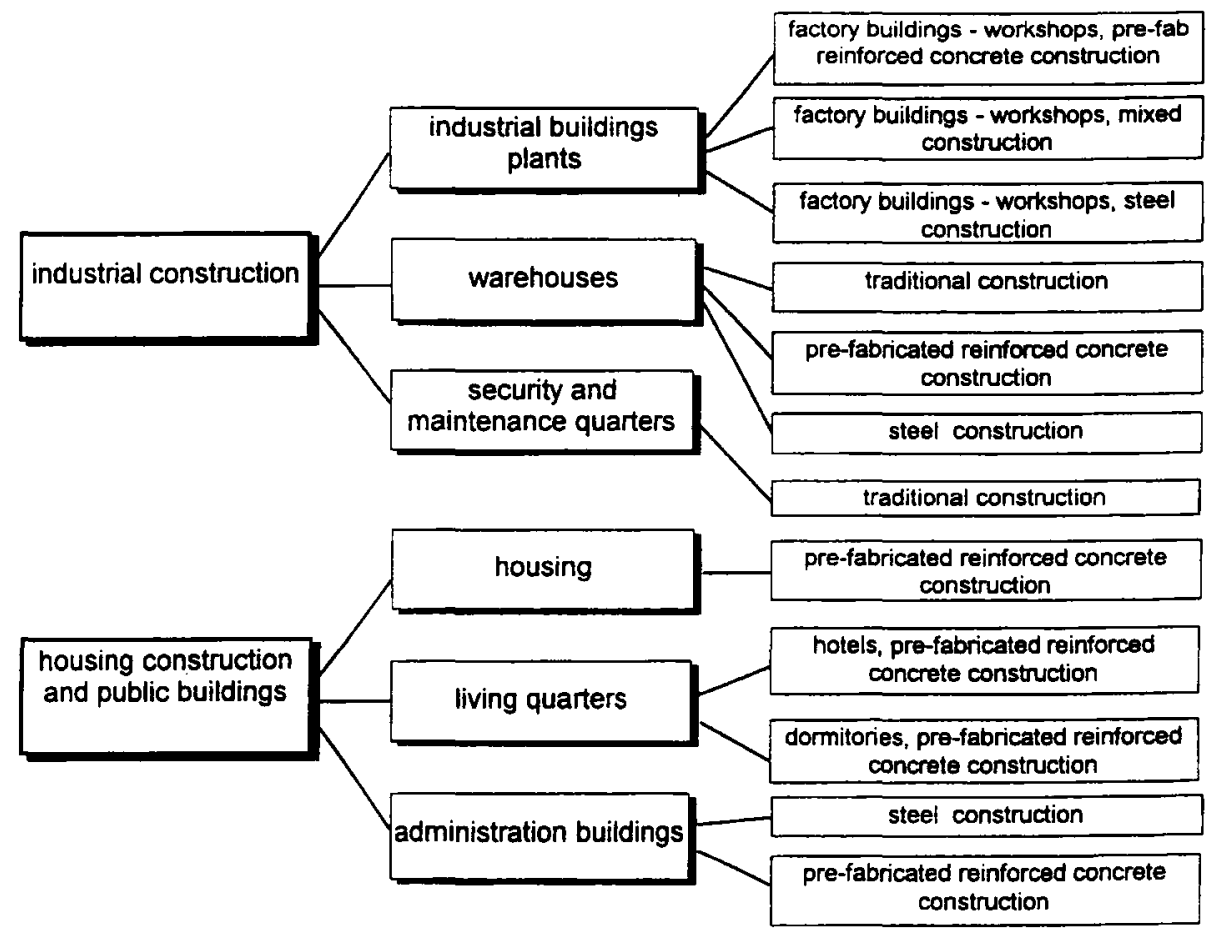

Fig 2. Classification of buildings analysed

Introducing the values of concrete mix demand at the preliminary design stage of a project permits determination of the projected demand for concrete mix. The balance of these values together with the practical capacity of a production plant allows for a calculation of the required number of plants.

\section{The modelling of concrete mix plant location prob- lems}

A number of modelling methods dealing with location problems are found in the literature, eg procedures branch and bound (Warszawski, [20]), graph theory (Woźnica, [27]), fuzzy dynamic programming (Huang et al., [15]) and those dealing with uncertainty conditions (Kamiński, [23]). The approach presented in the article is based on projected amounts of concrete mix demand with a non-linear cost-production function for concrete mix.

A number of options concerning the location of concrete mix plants are considered. The creation of such location options demands the consideration of a number of factors having different values which are not always open to mathematical expression. The prime location factors concerning the individual elements of the production line are presented in Fig 4. They were considered in the creation of a so-called function criterion as well as limiting conditions. The article presents only a generalised form of the model based on the production costs of raw materials, their transport, costs of production and transport of concrete mix and plant construction and installation costs.

The function criterion has the form:

$K_{c}=\sum_{z \in Z}\left(c_{z}+k_{z}\right) Q_{z}+\sum_{p \in P}\left(c_{p}+k_{p}\right) Q_{p}+\sum_{b \in B} k_{b} \rightarrow \min$,

$c_{z}$ - unit purchase cost of a given ingredient for concrete mix,

$k_{z}$ - unit cost of transport for raw materials for concrete mix,

$Q_{z}$-amount of purchased raw materials,

$c_{p}$ - unit cost of producing $1 \mathrm{~m}^{3}$ of concrete mix,

$k_{p}$ - unit cost of transporting $1 \mathrm{~m}^{3}$ of concrete mix,

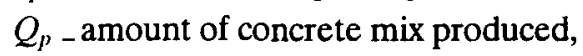

$k_{b}$ - costs of building plants at alternative sites.

The proposed mathematical model for solving the problem of localising concrete mix plants and its limitations has been presented by Celińska [28]. This model has been verified by Jagla [29] as well. The model introduces two kinds of variables:

- $X_{i j}$ describing the amount of concrete mix produced in the $i$-th location and destined to the $j$-th demand site.

- $Y_{i}$ describing the location site of the concrete mix plant; this variable may assume the binary value $(0,1)$ concerning the given location site. 

pre-fabricated reinforced
concrete buildings
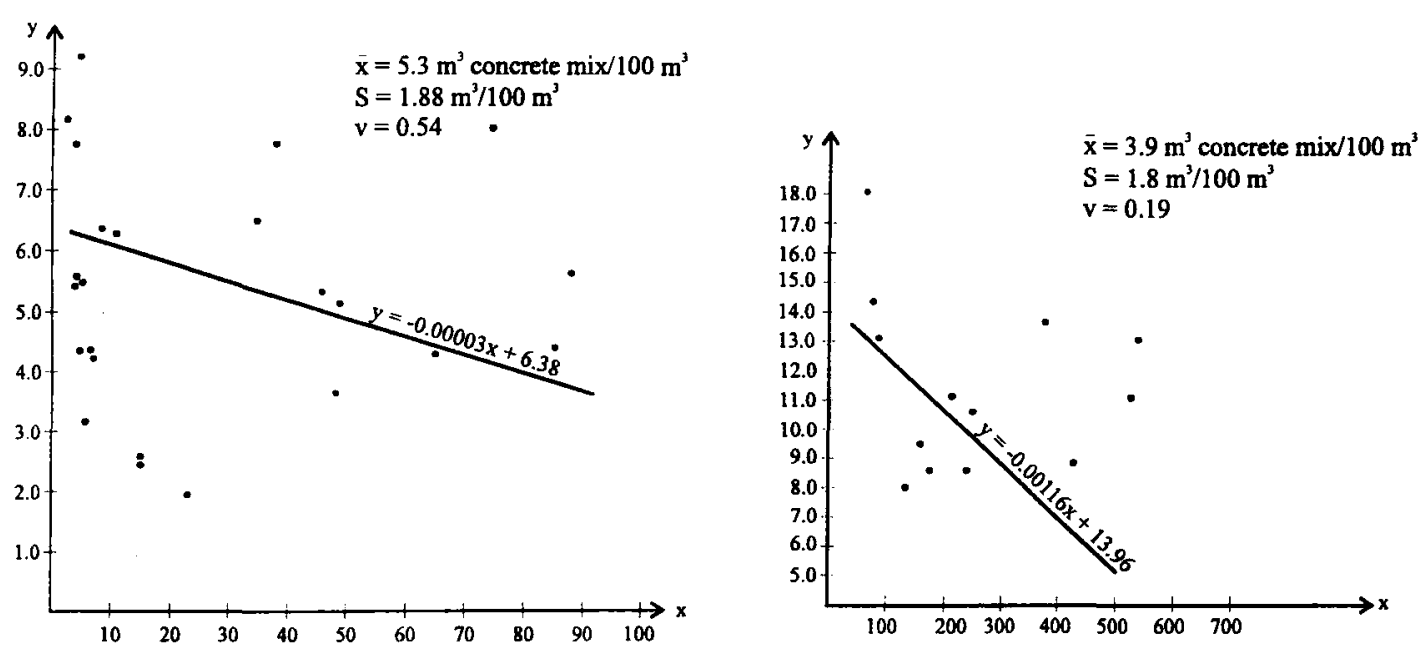

mixed construction
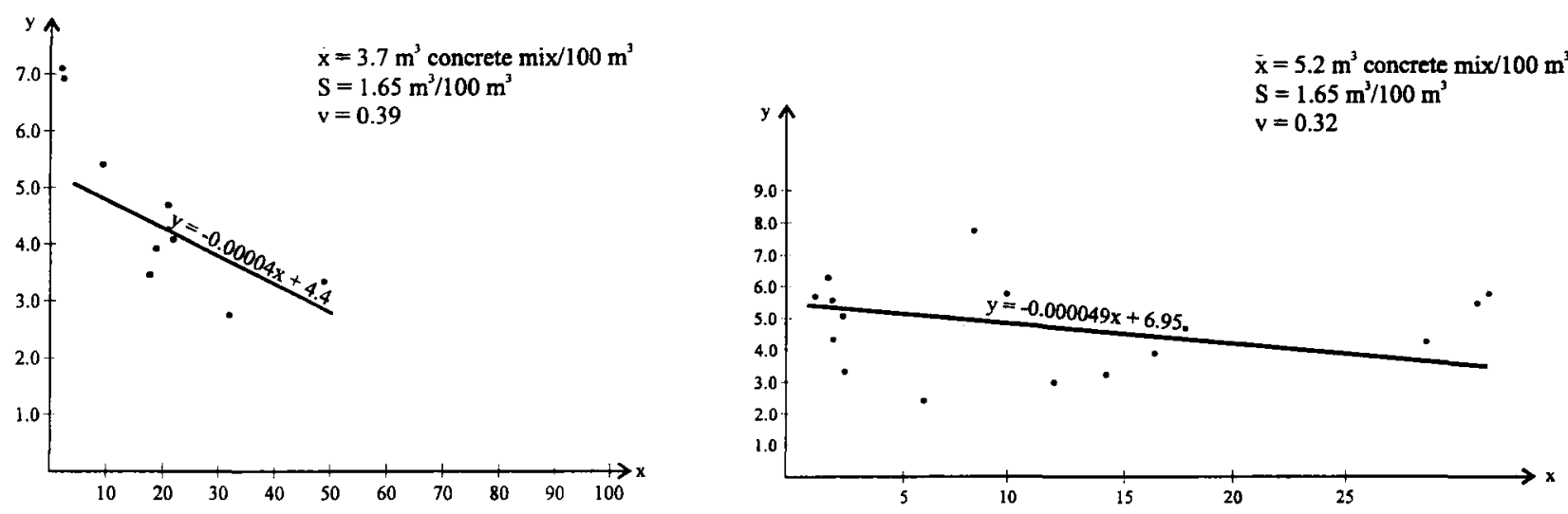

steel construction
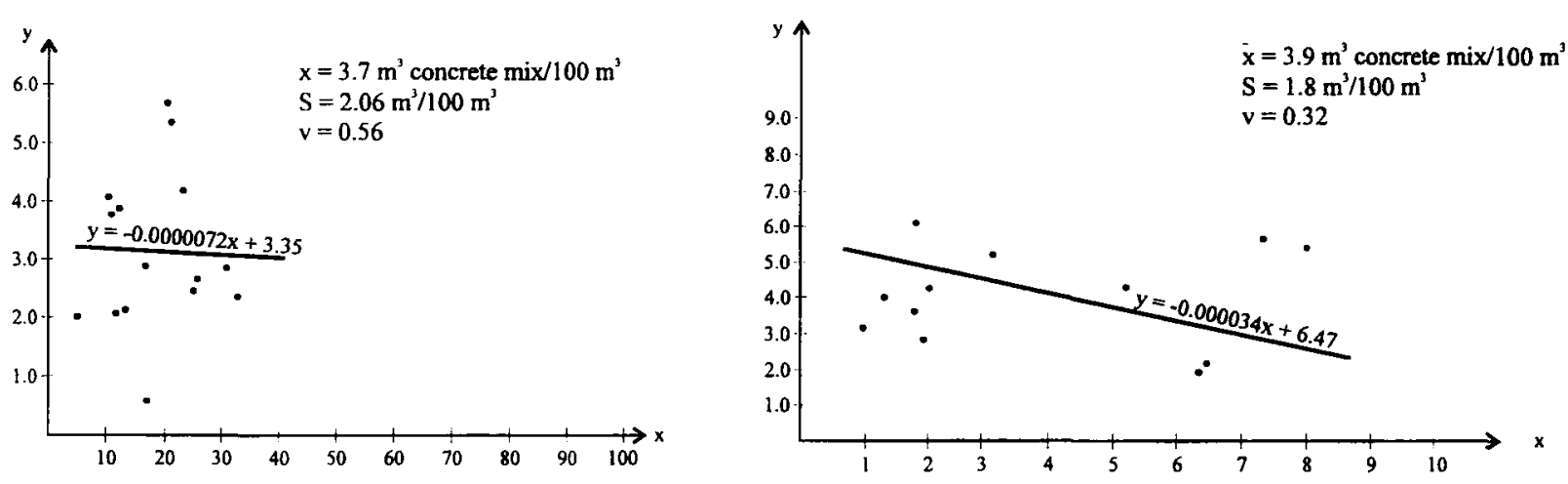

$\mathrm{x}$ - volume of building $\left[1000 \mathrm{~m}^{3}\right]$

$y$ - demand for concrete mix

Fig 3. Values of concrete mix demand indices for selected types of buildings 


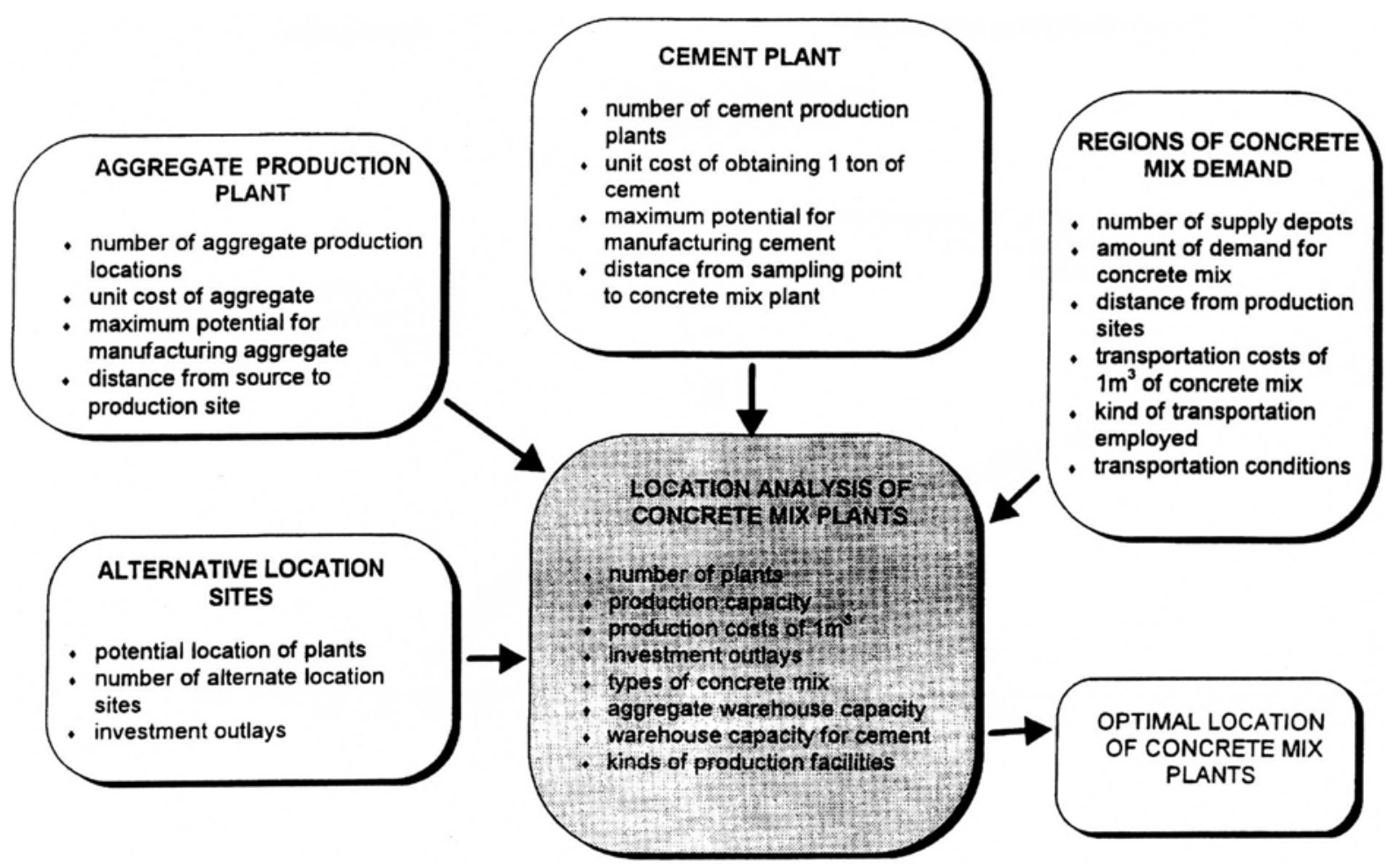

Fig 4. Location factors within individual elements of a production process

The model introduces 10 constraining conditions concerning the location and amount of raw materials produced, location and practical production capacity of concrete mix plants, and location and amount of concrete mix demanded. The assumptions of this model allowed for the change of multi-extreme and non-linear problem into integer one. The proposed method for describing the optimal number of concrete plant location sites is presented in Fig 5.

\section{Examples of data analysis}

The data analysis was conducted on calculations for Poznań and its environs. This allowed finding answers to the following questions:

- how many and on what sites of the area considered should there be installed concrete mix plants of a given capacity,

- how much concrete mix should be transported to certain demand sites from given production plants.

The data analysis was based on anticipated amounts of concrete mix needed obtained on the basis of concrete mix demand indices and plans for expanding building construction in the area considered. The production amounts were based on the practical capacities for manufacturing concrete mix. Location sites of currently functioning plants as well as location sites for alternate plants were considered.

Within the given area, the following were indicated:

- 87 concrete mix demand sites (within $0.5 \mathrm{~km}$ from the demand site, a sum total of demand was assumed),

- 14 concrete mix production sites,

- 12 alternate plant location sites,

- 2 levels of practical concrete mix production capacity, ie $31,000 \mathrm{~m}^{3} /$ year and $37,000 \mathrm{~m}^{3} /$ year. Levels were set for various seasonal indices, reliability of plant facilities and irregularity of demand for concrete mix.

Alternative sites of plant location were obtained by means of the division method (Kopociński, [30]) by selecting out subdivisions of the Poznan area where concrete mix plants could be located. The basis of the scale was a grid having side of $2 \mathrm{~km}$. Topographical analysis allowed for a precise location in specific areas where plants could be localised. The process of calculation included purchase costs of obtaining raw materials, the costs of production within the function of production capacity, costs of transporting the concrete mix from all production sites to demand sites.

Calculations were performed utilising standard software (Lindo, [31]) for discrete programming. 


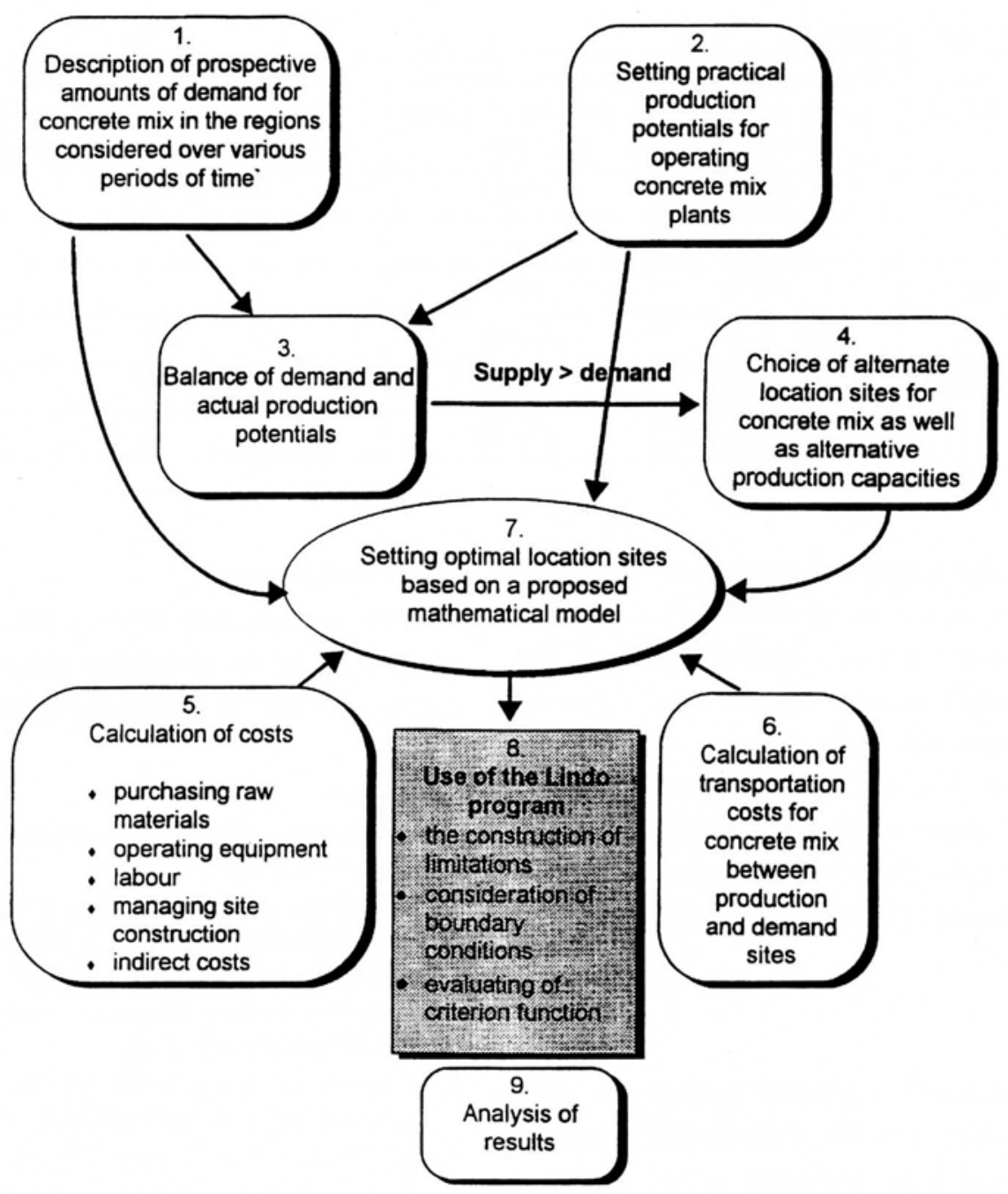

Fig 5. Diagram of functions necessary to obtain optimal location sites

The Lindo System Inc. - 1984 program [31] was developed for the purpose of offering solutions to problems based on intiger programming and quadratic programming. Seeking optimal locations for concrete mix production sites was conducted on the basis of the program version concerning intiger programming (according to a mathematical model). In the first stage numerical programming, the output data was prepared its appropriate use in the numerical process. The Lindo program operates on data matrices introduced into equations concerning limiting parameters and boundary conditions. A significant improvement of the computing process is achieved through the method of branch and bound. Such a solution, in a decided way, shortens and simplifies numerical computation.

The application of the Lindo program and discrete programming allowed for a description of location sites for production plants and the division of production capacity over a period of 3 years. The necessary production capacity thus obtained allowed for a choice of parameters and kinds of production facilities. These calculations were performed for 104 location situations. Optimal values obtained on the basis of calculations are presented in Table 1 . These include minimal values of costs at given practical plant production levels as well as differences between extreme location options.

Table 1 presents minimal values of criterion functions for horizontally presented practical production capacities of plants, ie $37,000 \mathrm{~m}^{3}$ and $31,000 \mathrm{~m}^{3}$ (per year), respectively. The given optimal sites were located as was the number of plants for minimal values of criterion functions (column 5). As well, the calculated percent differences between minimal and maximal values of the criterion function under the considered conditions are presented (column 6). 
Table 1. Results of optimal situations

\begin{tabular}{|c|c|c|c|c|c|}
\hline No & $\begin{array}{c}\text { Time } \\
\text { Periods }\end{array}$ & $\begin{array}{c}\text { Values of the Cri- } \\
\text { terion Function } \\
{[\text { PLN] }}\end{array}$ & $\begin{array}{c}\text { Level of Practical } \\
\text { Production Capacity } \\
{\left[\mathrm{m}^{3} / \text { year] }\right.}\end{array}$ & $\begin{array}{c}\text { Optimal Number } \\
\text { of Production } \\
\text { Plants }\end{array}$ & $\begin{array}{c}\text { Percent Differences } \\
\text { Between Values of Cri- } \\
\text { terion Functions }\end{array}$ \\
\hline \multirow{2}{*}{2.} & Year I & $55,743.37$ & 37,000 & 4 & 32.0 \\
\cline { 3 - 6 } & Year II & $57,882.80$ & 31,000 & 5 & 29.5 \\
\cline { 3 - 6 } & & $62,102.78$ & 37,000 & 5 & 26.0 \\
\hline 3. & Year III & $64,416.13$ & 31,000 & 5 & 27.8 \\
\cline { 3 - 6 } & & $54,509.75$ & 37,000 & 3 & 33.0 \\
\hline
\end{tabular}

In the first phase, the optimal number of concrete mix plants was 4 , at a level of $37,000 \mathrm{~m}^{3}$ of practical production capacity and 5 , at a level of $31,000 \mathrm{~m}^{3}$. The differences obtained between the values of the criterion functions expressed as percentages were $32 \%$ and $29 \%$, respectively. The change in location of demand points and their respective demand quantities in later phase allowed for an optimal realisation of production with fewer production plants. In phase III, this was 3 and 2 , respectively.

\section{Conclusions}

1. The presented approach permits the programming of location sites for production plants at the preliminary design stage according to the specifications of the project brief. This procedure allows for the flexible functioning of enterprises responsible for the production of the transported concrete mix.

2. The presented demand indices for concrete mix are verification of the existing linear relationship between the amount of concrete used and the volume. The given indices may be employed for the purpose of organising construction (utilisation of materials, storage area) as well as simplified estimating procedures.

3. Finding location sites for concrete mix plants were based on a topographic assessment of the area. Such a mathematically formulated approach may be used in the solution of all manner of location questions. Consideration of topographic conditions allows for a choice of possible plant location sites. The choice of optimal sites results from optimisation calculations.

4. The proposed methodology supported by software allows for the solution of location problems for the remaining elements of the construction camp.

\section{Acknowledgements}

The authors wish to thank the Poznan University of Technology for providing research grant (DS 11215/96 and BW 11-215/96) to support this work.

\section{References}

1. S. Soderman. Industrial location planning. New York Halsted Press, 1975.

2. M. Skibicki. Location decision making methods in construction industry, [in Polish], Ossolineum, 1977.

3. H.G. Daellenbach, J.A. George \& D.C. McNickle. Introduction to operations research techniques. Allyn and Bacon, Inc., Boston, 1993.

4. F. Harris \& R. McCaffer. Modern construction management. BSP Professional Books, Oxford, 1992.

5. R.L. Francis \& J.A. White. Facility layout and location. Prentice-Hall, Englewood Cliffs, New York, 1985.

6. Chr. Kruse., M. Zell and A.-W. Scheer. Architectural framework for the design of a simulation environment for decentralized production management // International Journal of Production Economics, Vols. 30-31, 1993, p. 355-364.

7. J.R. Wright, S.C. Egly \& H.W. Gallivan. A multiobjective model for seasonal personnel reassignment // Civil Engineering Systems, Vol. 3, 1986, p. 16-21.

8. A. Baskaran \& T. Stathopoulos. Prediction of wind effects on buildings using computational methods - review of the state of the art // Canadian Journal of Civil Engineering, Vol. 21, 1994, Nr. 5, p. 805-822.

9. D. Riopel \& A. Langevin. Optimizing the location of material transfer stations within layout analysis // International Journal of Production Economics, 22, 1991, p. 169-176.

10. H. Georgi. Cost-benefit analysis and public investment in transport: a survey. 1st Edn., Butterworths, London, 1973.

11. H.M. Weingartner. Capital budgeting of interrelated projects: survey and synthesis // Management Science, Vol. 12, 1966, p. 485-516.

12. G.L. Nemhauser and Z. Ullman. Discrete dynamic programming and capital allocation // Management Science, Vol. 15, 1969, p. 495-505. 
13. M. Olszewski. Transport infrastructure location in conditions of intensive site planning [in Polish] // Building Science Proc., No. 30, Warsaw: Warsaw Technical University Press, 1990.

14. M. Prystupa. Resource allocation models in the processes of building construction [in Polish] // Building Science Proc., No. 102, Warsaw: Warsaw Technical University Press, 1988.

15. G.H. Huang, B.W. Beatz \& G.G. Party Grey fuzzy dynamic programming: application to municipal solid waste management planning problems // Civil Engineering Systems, Vol. 11, 1991, No 1, p. 43-73.

16. A. Wijeratne \& S.C. Wirasinghe. Estimation of the number of fire stations and their allocated areas to minimize fire service and property damage costs // Civil Engineering Systems, Vol. 3, March, 1986, p. 2-6.

17. G.J. Meester. An expert system for a local planning environment // Working paper PLMOR-92-2, University of Twente, Enschede, 1992.

18. S. Suh, M.P. Kim \& T.J. Kim. ESMAN: an expert system for manufacturing site selection // Comput., Environ. and Urban Systems, Vol. 12, 1988, p. 239-252.

19. A. Warszawski. Layout and location problems - The quantitative approach // Building Science, Vol. 7, 1972, No. 1, p. 61-67.

20. A. Warszawski. Multidimensional location problems // Operations Research Quarterly, Vol. 20, 1974, No. 1, p. 165-179.

21. A. Warszawski. Industralization and robotics in building // A managerial approach. New York: Harper \& Row, 1990.

22. A. Warszawski \& E. Ishai. Long range planning of prefabrication industry in a national economy // Building and Environment, Vol. 17, 1982, No. 1.

23. St. Kamiński. Optimization of contractor's facilities for building construction [in Polish] // Building Science Proc., No. 79, Warsaw: Warsaw Technical University Press, 1983.

24. K. Lennerts and J. Knauer. Evaluation of algorithmus for the facility - plant - layout - problem transfered to site facilities // Computer Methods in Civil Engineering, Vol. 2, 1992, No. 4, p. 27-37.

25. A. Warszawski and S. Peer. Optimized location of facilities on building site // Operations Research Quarterly, Vol. 24, 1973, No. 1.

26. Ch. Powell. Some trends in relative costs of building types: description and interpretation // Construction Management and Economics, Vol. 4, 1986, p. 201-212.
27. J. Woznica. Optimizing of concrete mix location in construction industry [in Polish] // $\mathrm{PhD}$ Thesis, Wroclaw: Wroclaw Technical University, 1976.

28. M. Celińska-Mysław. Programming of concrete-mix plant location with regard to proposed method of demand dimension determination [in Polish]. PhD Thesis, Poznań Univ. of Technology, Poznań, 1990.

29. W. Jagła. Analisis of concrete mix plant location to supply wants of Poznan city, [in Polish]. MSc Thesis, Poznań University of Technology, IKB, 1992.

30. B. Kopociński About territorial division of Poland for sectors [in Polish] // Zastosowania Matematyki (Appl. Math.). Vol. V, 1961.

31. Lindo. LINDO linear, interactive and discrete optimizer, Lindo System Inc. Chicago, 1984.

\section{Iteikta 19971015}

\section{LINDO PROGRAMA BETONO MAIŠYMO GAMYKLOS VIETAI PARINKTI}

\section{Celińska-Mysław, O. Kapliński}

\section{S a n trauka}

Norint tinkamai išdèstyti statybos pramonès objektus, reikia gerai išmanyti šiuolaikines tendencijas, susijusias su gamybos užsakymų dydžiu, jų specifika ir kt. Šiame straipsnyje nagrinejjama betono maišymo gamyklu išdèstymo metodika, atsižvelgiant $\mathfrak{i}$ betono mišinio paklausos indeksus. Optimalios vietos betono mišiniui gaminti ieškoma pagal Lindo programą. Tyrimo metodika iliustruojama Poznanès (Lenkija) savivaldybès pavyzdžiais. Ji paremta matematiniu modeliu, kuri galima modifikuoti ir taikyti ieškant tinkamesnių aikštelių betono maišymo gamykloms statyti.

Maria CELINSSKA-MYSEAW. Doctor, Adjunct. Dept of Construction Engineering and Management. Poznań University of Technology. 60-965 Poznan, Poland. PhD in 1990. Research interests: construction engineering, cost calculation, control of production processes.

Oleg KAPLIŃSKI. Professor, DSc, PhD, Eng. Poznań University of Technology, Director of the Institute of Structural Engineering. Head of the Dept of Construction Engineering and Management. 60-965 Poznań, Poland. Author of 120 articles and books. Member of Ukrainian Building Academy. Research interests: organization and modelling of construction processes. 